\title{
Factors on Zakat (Tithe) Preference as a Tax Deduction in Aceh, Indonesia
}

\author{
Sri Nurhayati ${ }^{1 *}$ \\ Dodik Siswantoro 1 \\ 1 Universitas Indonesia, Kampus UI Depok 16424, Indonesia \\ *Corresponding Author Email: sri.nurhayati@ui.ac.id
}

\begin{abstract}
This paper aims to analyze the variables that affect zakat preference as a tax deduction. Samples are also analyzed and grouped to see some characteristics and patterns of specific issues. Structural Equation Model (SEM) is based on variance. SmartPLS is used to evaluate which variables affect the zakat preference. Samples are distributed to zakat institutions and the University in Aceh, Indonesia. Crosstab analysis can enrich the analysis of the paper. Very few people are aware of zakat as a tax deduction; however, local government has not approved the other permitted regulation of zakat as a taxable income deduction. In addition, only a few people have tax numbers that are used to claim overpaid tax (restitution). Surprisingly, motivation factor significantly affects zakat preference in a negative way. On the other hand, satisfaction factor is similar to Siswantoro and Nurhayati's 2012 findings, which is negative and insignificant. Motivation factor is positive, but insignificant.
\end{abstract}

Keywords: Zakat, tax, restitution, Aceh, SEM

\section{A. INTRODUCTION}

An attempt has been made to increase the number of zakat payers by giving an incentive, such as permitting zakat as a taxable income deduction in Indonesia since 1999. However, very few people have taken advantage of the deduction. This may be caused by the complexity involved in tax claims and insignificant benefits when compared to effort and return Siswantoro and Nurhayati, (2012). Thus, this may indicate the policy may not be successful. Therefore, in Aceh, Act No. 11/2006 was issued, which offered a bigger incentive. The act permitted people to claim zakat as a tax deduction. In fact, the act has not been effective yet as it has not been supported by tax regulation.

Recent research on similar issues has been conducted by (Anugrah, 2011), (Siswantoro \& Nurhayati (2012), and Prasetyo (2013). There are differences in previous research done on the significance of variables. This applies especially for satisfaction, which is considered insignificant by (Anugrah, 2011) but showed the opposite result, negative in zakat preference and insignificant (Siswantoro and Nurhayati, 2012).

This paper aims to analyze the affecting variables of zakat preference as a tax deduction. It is assumed that people are already aware of the policy on zakat as a tax deduction, considering the act was issued in 2006. The first part of this paper explains how zakat can be a tax deduction in Aceh, Indonesia. The second part shows previous research that deals with a similar issue and presents analysis tools that can cause different results. Subsequently, the third part is research 
methodology, which explains how the research was conducted. Finally, results are discussed on descriptive statistics, crosstab analysis, and SEM-SmartPLS.

\section{B. METHODS}

The research used structural equation modeling (SEM) for respondents' analyses in Aceh, Indonesia. The research was based on hard copy questionnaires. It was sent to zakat institutions (Baitul Mal, Rumah Zakat, and Lazis Muhammadiyah) and Universitas Syiah Kuala in Aceh in April 2013, then it was collected in June 2013 by visiting the institution. Each location was sent 100 questionnaires.

Respondents to the hard copy questionnaires represented people who are familiar with zakat and are at a higher education level. Total respondents were 171 people, while the analysis of SEM was based on the final data (131 data; see Table 4). Data were sent and collected from April until June 2013.

Table 1: Filter Data

\begin{tabular}{|l|c|r|}
\hline No. & Description & \multicolumn{1}{|c|}{ Total } \\
\hline 1 & Hard copy & 400 \\
\hline 2 & Not distributed & $(100)$ \\
\hline 3 & Total & 300 \\
\hline 4 & No return & $(129)$ \\
\hline 5 & Total & 171 \\
\hline 6 & Incomplete data & $(40)$ \\
\hline 7 & Data final & 131 \\
\hline
\end{tabular}

The research model refers to Table 3. There are three major variables used in the model, zakat as a tax deduction. The list of questions was copied from Siswantoro and Nurhayati's study (2012), with slight modifications on the related topic, especially on the zakat preference variable. A similar model is used to see the consistency and pattern of respondents with different objective preferences. The model framework can be found in Figure 2.

\section{RESULT AND DISCUSSIONS}

Historically, the government, the Islamic state, collected zakat. It is the third pillar of Islam to which Muslims must comply. Zakat is distributed to selected people: the poor, the needy, the manager, people in debt or in bondage, and wayfarers. On the other hand, there is also a tax that must be paid at that time. The object being taxed is usually land, trading goods, and so on. In the current context in which tax dominantly affects the economic system of a country, zakat should be excluded from the payment of tax. This is because zakat is actually distributed to selected people who also are covered by tax. Zakat simply replaces the existing account post in the budget. Therefore, there is an idea to have zakat as a tax deduction in Indonesia. Otherwise, those who pay zakat will be charged double as they also have to pay tax.

So far in Indonesia, zakat has been a taxable income deduction since 1999 (Act No. 38/1999). It is supported by the Ministry of Finance Act No. 17/2000 on taxable income (Minister of State 
Secretariat 2000). However, the complete supporting regulation was issued in 2010 (Governmental Regulation No. 60/2010 on zakat and religious charity) and in 2011 by the tax office (Directorate General of Tax 2011, No. PER-6/PJ/2011),(Directorate General of Tax 2011, No. PER-33/PJ/2011). It took almost 12 years for one policy to be fully implemented in Indonesia. Complete regulations mean all necessary and supporting regulations for one policy can be executed effectively.

The case of zakat as a tax deduction occurred in Aceh in 2006, by Act. No. 11/2006. Other supported regulations are Qanun (Islamic law) No. 10/2007 and Regional Regulation No. 60/2008(Regional Secretariat of Aceh, 2008). Both were issued by the Aceh government. No regulation was issued by the Ministry of Finance to support the act of zakat as a tax deduction. Therefore, the act cannot be implemented in Aceh for this case (see Figure 1). This is different from the act that permits zakat as a taxable income deduction.

Figure 1: Regulation hierarchy of Zakat as a tax deduction in Aceh.

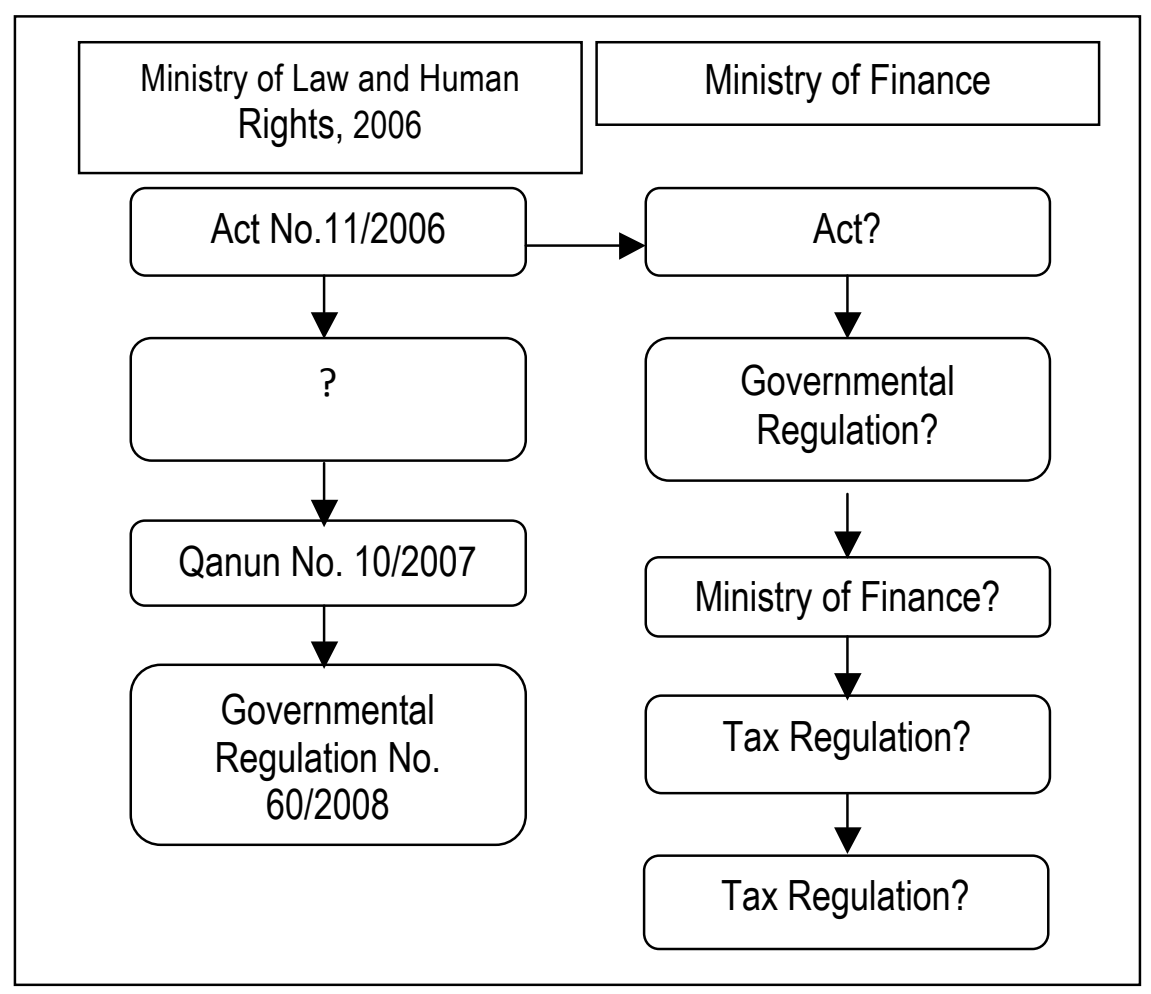

The difference between "zakat as a tax deduction" and "zakat as a taxable income deduction" is quite big (see Table 1). For "zakat as a tax deduction," muzakki (zakat payer) only pays the amount of tax (30), as the zakat deducts the total zakat. Yet if "zakat as a taxable income deduction" applies, it deducts the taxable income. It only decreases the total final amount a little bit (45 compared to 40.5). In the case of zakat as a tax deduction, the zakat only deducts the tax received by the government, but only if it is part of the local budget and the recipients are the same with if government took as tax. Zakat is replacing similar objects that are covered by tax before if zakat has not been applied. However, it would not totally ruin the local economy. Besides, it may attract people to pay taxes as it has the zakat incentive. 
Table 2: Comparison of Zakat as a Tax Deduction and Zakat as a Taxable Income Deduction

\begin{tabular}{|l|c|c|c|}
\hline \multicolumn{1}{|c|}{ Description } & $\begin{array}{c}\text { Zakat as a tax } \\
\text { deduction }\end{array}$ & $\begin{array}{c}\text { Zakat as not taxable } \\
\text { income deduction }\end{array}$ & $\begin{array}{c}\text { Zakat as a taxable } \\
\text { income deduction }\end{array}$ \\
\hline Taxable income & 100 & 100 & 100 \\
\hline Zakat & 15 & 15 & 15 \\
\hline Tax (rate 30\%) & 30 & 30 & 25.5 \\
\hline & & & 40.5 \\
\hline Total paid & 30 & 45 & \\
\hline
\end{tabular}

There is previous research that explored variables that affect zakat preference, stated in Table 2. They have differences in analysis tools, but not for the same case as zakat as a tax deduction. This is because it only occurs in Aceh for the case in Indonesia. In Malaysia, zakat is a full rebate as a tax deduction (Pollock, 2010). This can be an incentive because the zakat payer can deduct tax paid since 2005 (Bakar 2007). This should increase the number of zakat payments (Bakar and Rahman 2007).

Table 3: Previous Research on Variables to Zakat

\begin{tabular}{|c|c|c|c|c|}
\hline Author & $\begin{array}{l}\text { Independent } \\
\text { Variable }\end{array}$ & $\begin{array}{c}\text { Dependent } \\
\text { Variable }\end{array}$ & Result & Tools \\
\hline \multirow[t]{3}{*}{ Takidah (2004) } & Satisfaction & Commitment & Significant & Lisrel \\
\hline & Trust & & Significant & Mediating \\
\hline & Service quality & & Significant & \\
\hline \multirow[t]{2}{*}{ Rizal (2006) } & Satisfaction & Zakat preference & Significant & Lisrel \\
\hline & Trust & & Significant & \\
\hline \multirow[t]{2}{*}{ Anugrah (2011) } & Satisfaction & Zakat preference & Insignificant & Lisrel \\
\hline & Trust & & Significant & $\begin{array}{l}\text { State } \\
\text { employee } \\
\text { respondents }\end{array}$ \\
\hline \multirow[t]{2}{*}{ Jaelani (2008) } & Service quality & Zakat decision & Significant & Regression \\
\hline & Social marketing & & Significant & \\
\hline \multirow[t]{5}{*}{ Fatah (2006) } & Agama & Zakat decision & Affect & $\begin{array}{l}\text { Discriminant } \\
\text { analysis }\end{array}$ \\
\hline & Education & & & \\
\hline & Management & & Affect & \\
\hline & Income & & & \\
\hline & Age & & & \\
\hline \multirow[t]{4}{*}{$\begin{array}{l}\text { Sariningrum } \\
\text { (2011) }\end{array}$} & Faith & Zakat payment & & $\begin{array}{l}\text { Factor } \\
\text { analysis }\end{array}$ \\
\hline & Altruism & & & \\
\hline & Agama & & & \\
\hline & Reward & & & \\
\hline \multirow[t]{3}{*}{$\begin{array}{l}\text { Siswantoro and } \\
\text { Nurhayati } \\
(2012)\end{array}$} & Satisfaction & Zakat preference & Insignificant & $\begin{array}{l}\text { PLS (Partial } \\
\text { Least } \\
\text { Square) }\end{array}$ \\
\hline & Trust & & Significant & \\
\hline & Motivation & & Significant & \\
\hline Prasetyo (2013) & Satisfaction & Zakat preference & Significant & PLS \\
\hline
\end{tabular}




\begin{tabular}{|l|l|l|l|l|}
\hline & Trust & & Significant & \\
\hline & & & & $\begin{array}{l}\text { State } \\
\text { employee } \\
\text { respondents }\end{array}$ \\
\hline
\end{tabular}

Based on previous research, we would like to test the following hypotheses on this issue (refer to Table 3):

$\mathrm{H} 1$ : Satisfaction has a significant effect on the preference for zakat as a tax deduction.

$\mathrm{H} 2$ : Trust has a significant positive effect on preference for zakat as a tax deduction.

$\mathrm{H} 3$ : Motivation has a significant positive effect to preference for zakat as a tax deduction.

Table 4: Previous Research on Factors Affecting Zakat Payment

\begin{tabular}{|c|c|c|c|}
\hline $\begin{array}{l}\text { Independent } \\
\text { variable }\end{array}$ & $\begin{array}{l}\text { Dependent } \\
\text { variable }\end{array}$ & Result & Source \\
\hline Satisfaction & $\begin{array}{l}\text { Commitment } \\
\text { Preference } \\
\text { Zakat Payment } \\
\text { Preference } \\
\text { Preference } \\
\text { Preference }\end{array}$ & $\begin{array}{l}\text { (+) Sig. }{ }^{* * *} \\
(+) \text { Sig. }{ }^{* * *} \\
(+) \text { Sig. }{ }^{* * *} \\
(+) \\
(-) \\
(-)\end{array}$ & $\begin{array}{l}\text { Takidah (2004) } \\
\text { Rizal (2006) } \\
\text { Jaelani (2008) } \\
\text { Anugrah (2011) } \\
\text { Siswantoro and } \\
\text { Nurhayati (2012) } \\
\text { Prasetyo (2013) }\end{array}$ \\
\hline Trust & $\begin{array}{l}\text { Commitment } \\
\text { Preference } \\
\text { Preference } \\
\text { Preference } \\
\text { Preference }\end{array}$ & $\begin{array}{l}\text { (+) Sig. }{ }^{* * *} \\
\text { (+) Sig. }{ }^{* *} \\
\text { (+) Sig. }{ }^{* *} \\
\text { (+) Sig. }{ }^{* *} \\
\text { (+) Sig. }{ }^{* *}\end{array}$ & $\begin{array}{l}\text { Takidah (2004) } \\
\text { Rizal (2006) } \\
\text { Anugrah (2011) } \\
\text { Siswantoro and } \\
\text { Nurhayati (2012) } \\
\text { Prasetyo (2013) }\end{array}$ \\
\hline Motivation & $\begin{array}{l}\text { Zakat Payment } \\
\text { Preference }\end{array}$ & $\begin{array}{l}(+) \\
(+) \text { Sig. ** }\end{array}$ & $\begin{array}{l}\text { Saringrum (2011) } \\
\text { Siswantoro and } \\
\text { Nurhayati (2012) }\end{array}$ \\
\hline
\end{tabular}

The analysis starts with the descriptive analysis of a respondent's preference on the statements. It then follows with crosstab analysis, which relates and groups some characteristics of respondents. Finally, the structural equation modeling (SEM) - SmartPLS is used to classify supporting factors on zakat as a deductible tax in Aceh.

The main variables used in this research are satisfaction, trust, and motivation. Each variable is supported by some factors that are based on previous literature. The biggest average variables are on motivation, with three factors of motivation placed at the first and third ranks (see Table 5). On the other hand, the lowest are also for the motivation factor. The statement stated that "I am pleased when people know I pay zakat". This shows that respondents actually are humble. They do not want others to know that they pay zakat. In Islamic teaching, it may be good as it may destroy the intention of doing a good deed. The total average for motivation is 3.85 .

The second group, satisfaction, has a total average of 3.7, while trust has an average of 3.66. The preference for zakat as a deductible tax is 3.33 . Trust has the lowest average compared to the other categories. This is an interesting finding that shows that respondents do not have a strong trust in the zakat institution in Aceh. In fact, respondents are still in doubt of the statement that 
zakat can be tax deductible. Even though zakat has been tax deductible since 2006, not many people are aware of it in Aceh. The regulation ensures that zakat payers are not charged additional disbursements when they pay zakat because they can deduct the tax paid.

Table 5: Descriptive Statistics of Respondent Preference

\begin{tabular}{|l|l|}
\hline Factor & Mean \\
\hline $\mathrm{m} 3$ & 4.282 \\
\hline $\mathrm{m} 1$ & 4.229 \\
\hline $\mathrm{m} 2$ & 4.206 \\
\hline $\mathrm{s} 6$ & 3.878 \\
\hline $\mathrm{s} 5$ & 3.794 \\
\hline $\mathrm{t} 5$ & 3.786 \\
\hline $\mathrm{s} 11$ & 3.771 \\
\hline $\mathrm{t} 2$ & 3.763 \\
\hline $\mathrm{t} 3$ & 3.733 \\
\hline $\mathrm{t} 4$ & 3.733 \\
\hline $\mathrm{t} 1$ & 3.725 \\
\hline $\mathrm{s} 1$ & 3.710 \\
\hline $\mathrm{s} 12$ & 3.710 \\
\hline $\mathrm{s} 8$ & 3.695 \\
\hline $\mathrm{s} 9$ & 3.695 \\
\hline $\mathrm{t} 8$ & 3.687 \\
\hline $\mathrm{s} 4$ & 3.679 \\
\hline $\mathrm{s} 3$ & 3.664 \\
\hline $\mathrm{s} 10$ & 3.634 \\
\hline $\mathrm{t} 10$ & 3.626 \\
\hline $\mathrm{s} 2$ & 3.611 \\
\hline $\mathrm{t} 9$ & 3.603 \\
\hline $\mathrm{s} 7$ & 3.565 \\
\hline $\mathrm{t} 7$ & 3.550 \\
\hline $\mathrm{t} 6$ & 3.481 \\
\hline $\mathrm{s} 13$ & 3.427 \\
\hline $\mathrm{z}$ & 3.336 \\
\hline $\mathrm{m} 4$ & 2.687 \\
\hline
\end{tabular}

The awareness of the zakat as a deductible tax can be seen also from respondents who have tax numbers. Only $64.1 \%$ of respondents have tax numbers (Nomor Pokok Wajib Pajak-NPWP). Male respondents have bigger percentages than female respondents $(37.1 \%>27.1 \%$; see Table 6$)$. This may be because male respondents are workers and employees and they must have tax numbers for paying income taxes. Otherwise, if they do not have tax numbers, they will be charged a higher amount. However, claiming a deduction for taxable income is impossible without a tax number (under the current applied regulation). In fact, this research finds that no one has claimed tax restitution as a zakat payment. Nationally, this policy has been implemented throughout Indonesia, but not in Aceh as it has not been recognized by Islamic regulation. $A$ similar problem has occurred for zakat as a deductible tax. 
Table 6: Cross Tabulation of Tax Number and Sex

\begin{tabular}{|l|c|c|c|c|}
\hline \multirow{4}{*}{ Sex } & & \multicolumn{2}{|c|}{ Tax Number } & \multirow{2}{*}{ Total } \\
\cline { 2 - 4 } & & Yes & No & \\
\cline { 2 - 5 } & Male & 63 & 14 & 77 \\
\cline { 2 - 5 } & $\%$ & 37.1 & 8.2 & 45.3 \\
\cline { 2 - 5 } & Female & 46 & 47 & 93 \\
\cline { 2 - 5 } & $\%$ & 27.1 & 27.6 & 54.7 \\
\hline \multirow{4}{*}{ Total } & & 109 & 61 & 170 \\
\cline { 2 - 5 } & $\%$ & 64.1 & 35.9 & 100 \\
\hline
\end{tabular}

In fact, $36.5 \%$ of respondents paid zakat directly to recipients and not through a zakat institution. It has become an important task for local zakat institutions to attract people to pay zakat directly to them (see Table 7). Some people still believe that it would be more effective if zakat was disbursed directly to the recipients. A second rank is taken by an employer (28.3\%), which is usually conducted by a government office. It coordinates with nearby Baitul Mal as a government zakat institution; $13.2 \%$ is paid to registered zakat institutions. These zakat institutions are Dompet Dhuafa, PKPU, Rumah Zakat, and Lazis Muhammadiyah. Based on Qanun No. 10/2007(Regional Secretariat of Aceh, 2007), these institutions cannot collect zakat after 2012. However, there is no sanction if they still manage zakat funds in Aceh. To minimize conflicts, they collect other zakat funds such as shadaqah (charity) and infaq (grants).

Fifteen out of 66 employees who work at government offices pay zakat directly to the recipients. While less than $50 \%$ (31 employees) pay zakat by salary cut. This may show that not all government institutions coordinate with Baitul Mal to collect zakat funds. The intriguing issue is nongovernmental office employee types (the private sector) tend to not take zakat payment from their salary. In this case, Baitul Mal should be able to ask private organizations to get involved in their zakat collection coordination.

Table 7: Cross Tabulation of Company Type Payers and Zakat Destination

\begin{tabular}{|c|c|c|c|c|c|c|c|}
\hline & & \multicolumn{5}{|c|}{ Zakat Destination } & \multirow[b]{2}{*}{ Tota } \\
\hline & & Direct & $\begin{array}{l}\text { Reg. } \\
\text { LAZ }\end{array}$ & $\begin{array}{l}\text { Not } \\
\text { yet }\end{array}$ & Mosque & $\begin{array}{c}\text { Salary } \\
\text { Take }\end{array}$ & \\
\hline \multirow{11}{*}{$\begin{array}{c}\text { Company } \\
\text { Type }\end{array}$} & Government & 15 & 8 & 6 & 6 & 31 & 66 \\
\hline & $\%$ & 9.4 & 5 & 3.8 & 3.8 & 19.5 & 41.5 \\
\hline & Private & 12 & 8 & 6 & 5 & 11 & 42 \\
\hline & $\%$ & 7.5 & 5 & 3.8 & 3.1 & 6.9 & 26.4 \\
\hline & SOE & 2 & 2 & & & 3 & 7 \\
\hline & $\%$ & 1.3 & 1.3 & & & 1.9 & 4.4 \\
\hline & $\mathrm{MNC}$ & 1 & & & & & 1 \\
\hline & $\%$ & .6 & & & & & \\
\hline & Nat.Private & 8 & 1 & & & & 9 \\
\hline & $\%$ & 5 & .6 & & & & \\
\hline & Others & 20 & 2 & 6 & 6 & & 34 \\
\hline
\end{tabular}




\begin{tabular}{|l|c|c|c|c|c|c|c|}
\hline & $\%$ & 12.6 & 1.3 & 3.8 & 3.8 & & 21.4 \\
\hline \multirow{3}{*}{ Total } & & 58 & 21 & 18 & 17 & 45 & 159 \\
\cline { 2 - 8 } & $\%$ & 36.5 & 13.2 & 11.3 & 10.7 & 28.3 & 100 \\
\hline
\end{tabular}

In fact, only $23.4 \%$ of respondents know that zakat can be tax deductible, even though the regulation was issued in 2006 (see Table 8). Therefore, people should have already been aware of this regulation. The higher education level does not increase the level of awareness about zakat as a deductible tax, except for graduate level (17 out of 44 , or $38.6 \%$ ). The issue of zakat as a deductible tax is not simple and needs aggressive socialization. In addition, the regulation has not been effective yet, as it is not supported by the supporting tax regulation. In order to be effective, the act on tax must be revised and accommodate zakat as a deductible tax by the House of Assembly.

Table 8: Cross Tabulation of "Zakat Deductible Tax" and Education

\begin{tabular}{|l|c|c|c|c|}
\hline \multirow{4}{*}{} & & \multicolumn{2}{|c|}{ Zakat as Tax Deduction } & \multirow{2}{*}{ Total } \\
\cline { 2 - 5 } & & Yes & No & \\
\hline \multirow{5}{*}{ Education } & $<$ Junior HS & 1 & 2 & 3 \\
\cline { 2 - 5 } & $\%$ & 6 & 1.2 & 1.8 \\
\cline { 2 - 5 } & Senior HS & 8 & 30 & 38 \\
\cline { 2 - 5 } & $\%$ & 4.8 & 18 & 22.8 \\
\cline { 2 - 5 } & Diploma & 4 & 11 & 15 \\
\cline { 2 - 5 } & $\%$ & 2.4 & 6.6 & 9 \\
\cline { 2 - 5 } & Undergraduate & 9 & 58 & 67 \\
\cline { 2 - 5 } & $\%$ & 5.4 & 34.7 & 40.1 \\
\cline { 2 - 5 } & Graduate & 17 & 27 & 44 \\
\cline { 2 - 5 } & $\%$ & 10.2 & 16.2 & 26.3 \\
\hline Total & & 39 & 128 & 167 \\
\cline { 2 - 5 } & & 23.4 & 76.6 & 100 \\
\hline
\end{tabular}

Table 9: Cross Tabulation of "Zakat Tax-Deductible Income" and Education

\begin{tabular}{|c|c|c|c|c|}
\hline & & \multicolumn{2}{|c|}{$\begin{array}{c}\text { Zakat as Taxable Income } \\
\text { Deduction }\end{array}$} & \multirow[t]{2}{*}{ Total } \\
\hline & & Yes & No & \\
\hline \multirow{10}{*}{ Education } & $<$ Junior HS & 0 & 3 & 3 \\
\hline & $\%$ & & 1.8 & 1.8 \\
\hline & Senior HS & 7 & 31 & 38 \\
\hline & $\%$ & 4.2 & 18.8 & 23 \\
\hline & Diploma & 5 & 10 & 15 \\
\hline & $\%$ & 3 & 6.1 & 9.1 \\
\hline & Undergraduate & 8 & 58 & 66 \\
\hline & $\%$ & 4.8 & 35.2 & 40 \\
\hline & Graduate & 16 & 27 & 43 \\
\hline & $\%$ & 9.7 & 16.4 & 26.1 \\
\hline Total & & 36 & 129 & 165 \\
\hline
\end{tabular}




\begin{tabular}{|l|l|l|l|l|}
\hline & $\%$ & 21.8 & 78.2 & 100 \\
\hline
\end{tabular}

The interesting finding is that the respondents' awareness of zakat as a taxable income deduction is only $21.8 \%$ (see Table 9 ). This is lower than the previous result, although the act of the corresponding issue was issued in 1999 (Act No. 38/1999) and supported by technical regulation in 2010 (Governmental Regulation No. 60/2010). Despite national legalization, this act is not recognized in Aceh because it is not supported by Islamic regulation. In addition, the effect is not considered significant and the process is complicated. The level of awareness on this issue is similar to the previous issue.

The main reason people do not propose restitution for overpaid dues to zakat payment is unawareness of the issue. Other reasons are complicated processes and laziness to apply for restitution. The process of restitution requires a site check and many phases and can result in larger tax charges if negligence is found.

Table 10: Cross Tabulation of the Reason for Zakat Maal Payment and Not Restitution

\begin{tabular}{|c|c|c|c|c|c|c|c|}
\hline & & \multicolumn{5}{|c|}{ Reason for Not Restitution } & \multirow{2}{*}{ Total } \\
\cline { 2 - 7 } & & Difficult & Complicated & Lazy & $\begin{array}{c}\text { Not } \\
\text { Agree }\end{array}$ & Other & \\
\hline \multirow{6}{*}{ Total } & Yes & 5 & 17 & 9 & 10 & 31 & 72 \\
\cline { 2 - 7 } & $\%$ & 3.3 & 11.3 & 6 & 6.7 & 20.7 & 48 \\
\cline { 2 - 7 } & No & 1 & 5 & 19 & 4 & 49 & 78 \\
\cline { 2 - 7 } & $\%$ & .7 & 3.3 & 12.7 & 2.7 & 32.7 & 52 \\
\cline { 2 - 7 } & $\%$ & 4 & 22 & 28 & 14 & 80 & 150 \\
\hline
\end{tabular}

The relationship between income level and the compliance to zakat payment is positive-the bigger the income, the higher the percentage of zakat maal payment (see Table 11). Zakat maal is based on the wealth of the people with a minimum amount of $85 \mathrm{gr}$ gold. If the wealth for 1 year is below $85 \mathrm{gr}$ gold, a Muslim does not have to pay zakat, which apparently occurs for people whose salaries are below Rp2 $\mathrm{mn}$ (percentage of paying zakat is 12 out of 51). The payment increases for the group with a salary range of Rp2-5 mn. Then, it is almost $100 \%$ for the group with a salary range of Rp5-10mn, and it is $100 \%$ for people with a salary range of Rp10-15 mn. There is no respondent whose salary is above $\mathrm{Rp} 25 \mathrm{mn}$.

Table 11: Cross Tabulation of Income and Zakat Maal Payment

\begin{tabular}{|l|c|l|l|l|}
\hline \multirow{4}{*}{} & & \multicolumn{2}{|c|}{ Zakat Maal Payment } & \multirow{2}{*}{ Total } \\
\cline { 2 - 5 } & & Yes & No & \\
\hline \multirow{4}{*}{$\begin{array}{l}\text { Income (in } \\
\text { IDR million) }\end{array}$} & $<2$ & 12 & 39 & 51 \\
\cline { 2 - 5 } & $2-5$ & 7.7 & 25 & 32.7 \\
\cline { 2 - 5 } & $\%$ & 24.4 & 39 & 77 \\
\cline { 2 - 5 } & $5-10$ & 24 & 25 & 49.4 \\
\cline { 2 - 5 } & $\%$ & 15.4 & .6 & 25 \\
\cline { 2 - 5 } & $10-25$ & 3 & - & 3 \\
\hline
\end{tabular}




\begin{tabular}{|l|c|c|c|c|}
\hline \multirow{4}{*}{ Total } & $\%$ & 1.9 & & 1.9 \\
\cline { 2 - 5 } & $>25$ & & & \\
\cline { 2 - 5 } & $\%$ & & & \\
\hline & & 77 & 79 & 156 \\
\cline { 2 - 5 } & $\%$ & 49.4 & 50.6 & 100 \\
\hline
\end{tabular}

Table 12: Cross Tabulation of Zakat Salary Payment and Income

\begin{tabular}{|c|c|c|c|c|}
\hline & & \multicolumn{2}{|c|}{$\begin{array}{c}\text { Zakat Salary (Income) } \\
\text { Payment }\end{array}$} & \multirow[t]{2}{*}{ Total } \\
\hline & & Yes & No & \\
\hline \multirow{10}{*}{$\begin{array}{l}\text { Income (in } \\
\text { IDR million) }\end{array}$} & $<2$ & 10 & 40 & 50 \\
\hline & $\%$ & 6.5 & 26 & 32.5 \\
\hline & $2-5$ & 39 & 39 & 78 \\
\hline & $\%$ & 25.3 & 25.3 & 50.6 \\
\hline & $5-10$ & 13 & 11 & 24 \\
\hline & $\%$ & 8.4 & 7.1 & 15.6 \\
\hline & $10-25$ & 2 & & 2 \\
\hline & $\%$ & 1.3 & & 1.3 \\
\hline & $>25$ & & & \\
\hline & $\%$ & & & \\
\hline \multirow[t]{2}{*}{ Total } & & 64 & 90 & 154 \\
\hline & $\%$ & 41.6 & 58.4 & 100 \\
\hline
\end{tabular}

On the other hand, the percentage of salary zakat payment is lower than maal zakat payment (see Table 12). This is because not all people are aware of salary zakat, which is relatively new and usually handled by each company. This type of zakat is simple as it is just deducted from the salary directly. This zakat does not require other deductions from the wealthy for the zakat object, such as debt and third party rights. However, people who have paid salary zakat for the current year must also pay for maal (wealth) zakat for 1 year ago.

More male respondents pay zakat maal compared to female respondents (38 out of 73; see Table 13). On the contrary, it is the opposite for salary zakat payment (see Table 14). Male respondents prefer paying maal zakat to salary zakat. While on average, the percentage of zakat maal payment is higher than the salary zakat payment.

Table 13: Cross Tabulation of Sex and Zakat Maal Payment

\begin{tabular}{|l|c|c|c|c|}
\hline \multirow{4}{*}{} & & \multicolumn{2}{|l|}{$\begin{array}{l}\text { Zakat Maal } \\
\text { Payment }\end{array}$} & \multirow{3}{*}{ Total } \\
\cline { 2 - 4 } & & Yes & No & \\
\hline \multirow{4}{*}{ Sex } & Male & 38 & 35 & 73 \\
\cline { 2 - 5 } & $\%$ & 23.6 & 21.7 & 45.3 \\
\cline { 2 - 5 } & Female & 41 & 47 & 88 \\
\cline { 2 - 5 } & $\%$ & 25.5 & 29.2 & 54.7 \\
\hline \multirow{3}{*}{ Total } & & 79 & 82 & 161 \\
\cline { 2 - 5 } & $\%$ & 49.1 & 50.9 & 100 \\
\hline
\end{tabular}


Table 14: Cross Tabulation of Sex and Zakat Salary Payment

\begin{tabular}{|l|c|c|c|c|}
\hline \multirow{4}{*}{ Sex } & & \multicolumn{2}{|c|}{$\begin{array}{c}\text { Zakat Salary } \\
\text { (Income) Payment }\end{array}$} & \multirow{2}{*}{ Total } \\
\cline { 2 - 4 } & & Yes & No & \\
\hline \multirow{5}{*}{ Total } & Male & 29 & 42 & 71 \\
\cline { 2 - 5 } & $\%$ & 18.2 & 26.4 & 44.7 \\
\cline { 2 - 5 } & Female & 37 & 51 & 88 \\
\cline { 2 - 5 } & $\%$ & 23.3 & 32.1 & 55.3 \\
\cline { 2 - 5 } & $\%$ & 66 & 93 & 159 \\
\hline
\end{tabular}

Low participation in zakat salary payment is an important issue that should be addressed. This is because zakat, as the third pillar of Islam, is an obligation for Muslims. Furthermore, zakat benefits the society and social development. The government should be aggressive in promoting zakat within society and develop a good infrastructure to enable people to pay zakat easily.

Table 15: Cross Tabulation of Status and Zakat Maal Payment

\begin{tabular}{|l|c|c|c|c|}
\hline \multirow{4}{*}{} & & \multicolumn{2}{|l|}{$\begin{array}{l}\text { Zakat Maal } \\
\text { Payment }\end{array}$} & \multirow{2}{*}{ Total } \\
\cline { 2 - 4 } & & Yes & No & \\
\hline Status & $\begin{array}{c}\text { Not } \\
\text { Married }\end{array}$ & 7 & 22 & 29 \\
\cline { 2 - 5 } & $\%$ & 4.3 & 13.7 & 18 \\
\cline { 2 - 5 } & Married & 68 & 57 & 125 \\
\cline { 2 - 5 } & $\%$ & 42.2 & 35.4 & 77.6 \\
\cline { 2 - 5 } & Widowed & 4 & 3 & 7 \\
\cline { 2 - 5 } & $\%$ & 2.5 & 1.9 & 4.3 \\
\hline Total & & 79 & 82 & 161 \\
\cline { 2 - 5 } & $\%$ & 49.1 & 50.9 & 100 \\
\hline
\end{tabular}

Married respondents have a larger percentage of maal zakat payments. This may indicate that married people usually have better and more stable economic conditions compared to single people (see Table 15). However, there are married respondents who do not make maal zakat payments due to spouse factors and other factors that should be further identified. 
Figure 2: First model result.

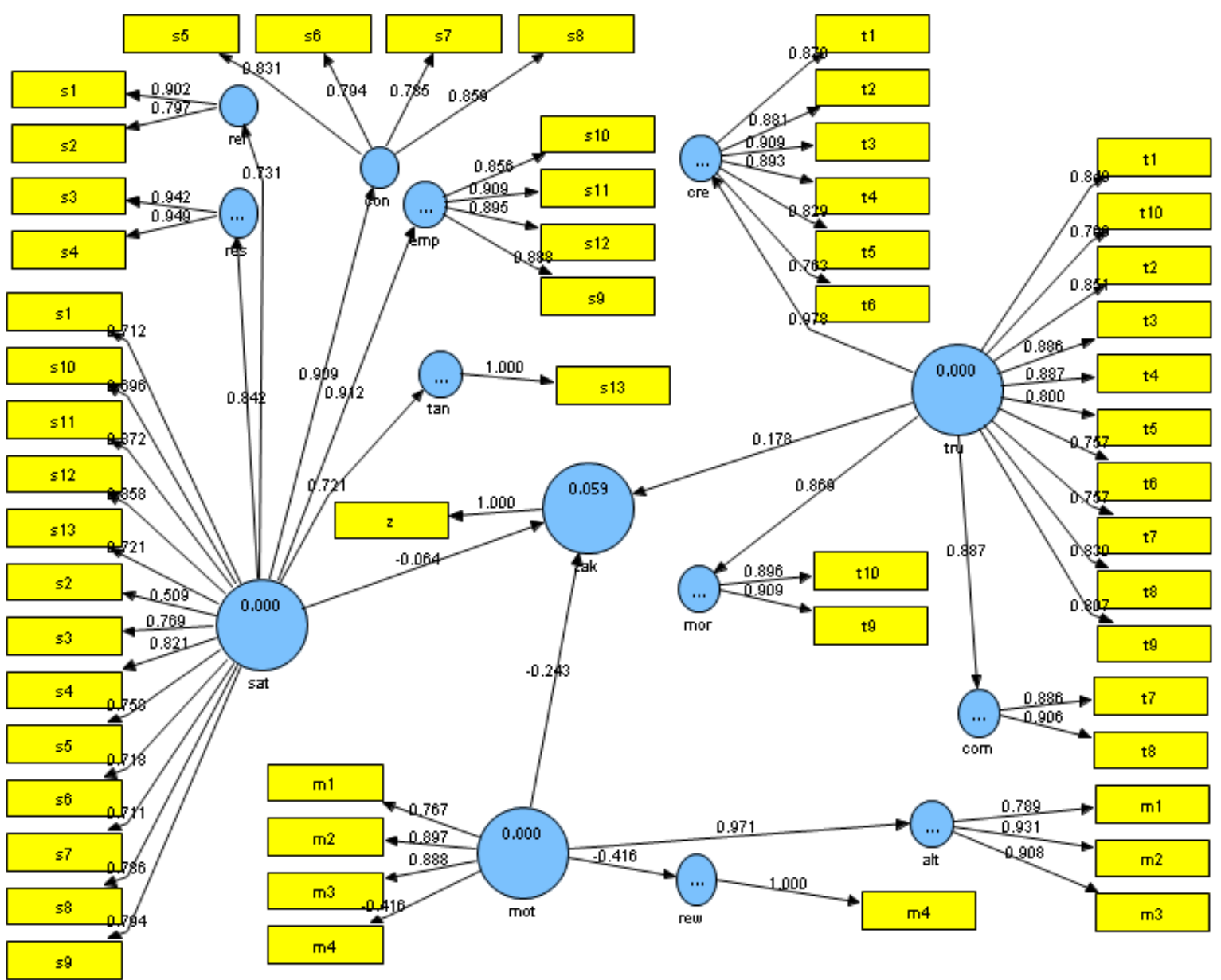

The research model is similar to that of (Siswantoro and Nurhayati, 2012) in that it focuses on zakat as a taxable income deduction. In this model, we changed the preference variable to zakat as a tax deduction. Some modifications were made on screening information, relevant variables, and specific cases. 
Figure 3: Model result after loading $>0.7$.

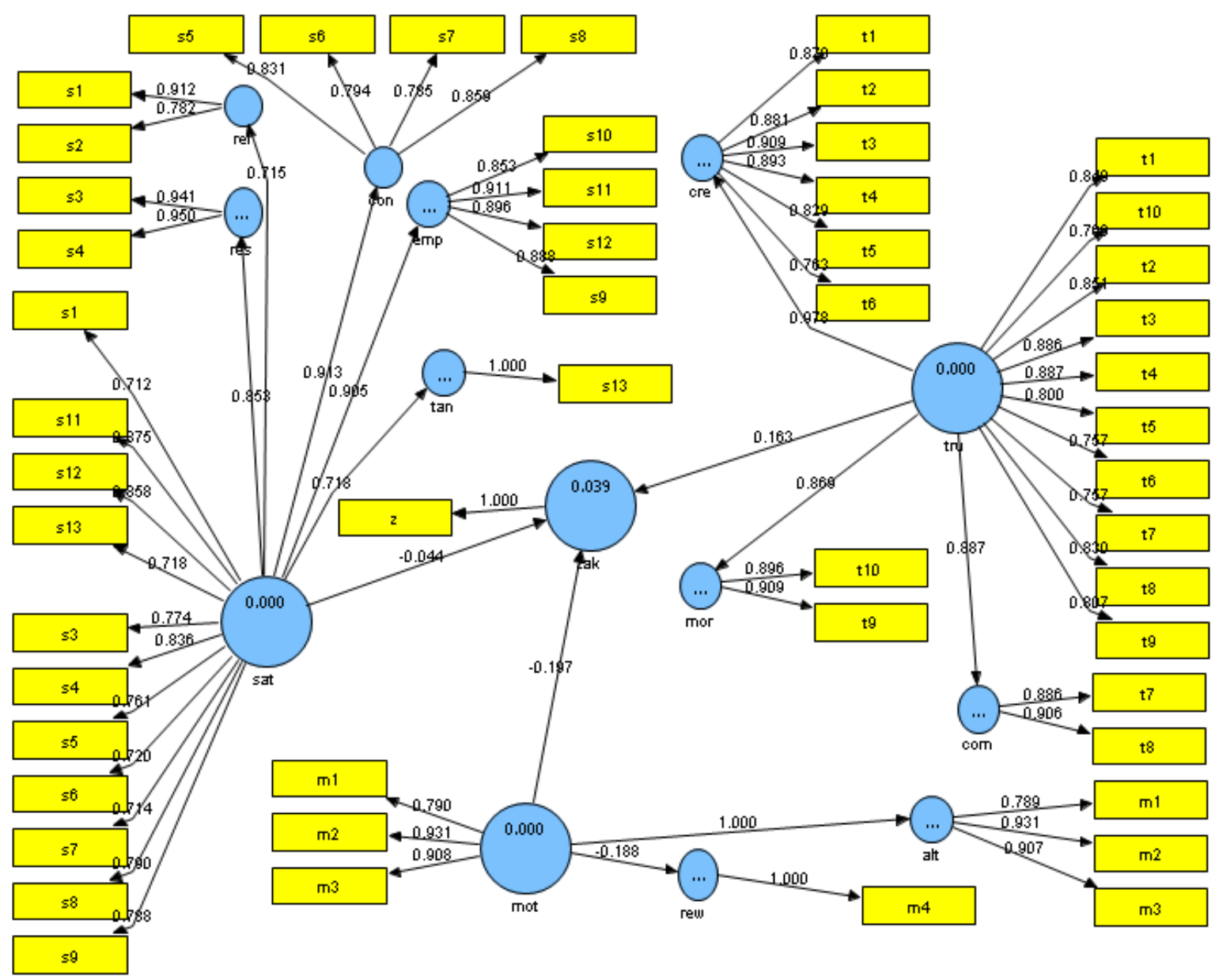

The figure above shows that many factors have loading factors bigger than 0.7. This is a good thing as there is a strong preference in these statements. Factors lower than 0.7 are factors $s 2$, $\mathrm{s} 10$, and $\mathrm{m} 4$, all from repeated indicators. Repetitive factors that directly affect the variables have lower loading factors in this case.

Factors lower than 0.7 shows that respondents do not have a consistent pattern to affect other variables. Those variables are as follows:

s2 = Zakat disbursement procedure is on the right target.

$s 10=$ I can use technology to pay zakat at a zakat institution.

$\mathrm{m} 4=$ I am pleased when others know I paid zakat.

Low factor loading on s2 shows that respondents have different preferences on statements of zakat that have been disbursed to the right people. The problem in zakat management lies not only in the collection process but also in the disbursement. Low factor loading on s10 should become a concern as respondents should be able to pay zakat easily using current technologyfor example, by using an ATM, online banking, mobile gadgets, and so forth. The easier it is to pay zakat using technological facilities, the more zakat funds could be collected. Lastly, low factor 
loading on $\mathrm{m} 4$ implies that respondents feel that it is not important to let others know they have paid zakat. This signifies different meanings for motivation by the respondents.

Table 16: Results of Smart PLS

\begin{tabular}{|l|l|c|c|c|c|c|}
\hline & AVE & Communality & R Square & $\begin{array}{c}\text { Composite } \\
\text { Reliability }\end{array}$ & $\begin{array}{c}\text { Cronbach's } \\
\text { Alpha }\end{array}$ & Redundancy \\
\hline alt & 0.771 & 0.771 & 0.999 & 0.909 & 0.848 & 0.771 \\
\hline com & 0.802 & 0.802 & 0.786 & 0.890 & 0.754 & 0.629 \\
\hline con & 0.669 & 0.669 & 0.833 & 0.889 & 0.834 & 0.557 \\
\hline cre & 0.737 & 0.737 & 0.955 & 0.943 & 0.928 & 0.704 \\
\hline emp & 0.787 & 0.787 & 0.819 & 0.936 & 0.910 & 0.636 \\
\hline mor & 0.814 & 0.814 & 0.755 & 0.897 & 0.772 & 0.614 \\
\hline mot & 0.771 & 0.771 & & 0.909 & 0.848 & \\
\hline rel & 0.721 & 0.721 & 0.511 & 0.837 & 0.628 & 0.357 \\
\hline res & 0.893 & 0.893 & 0.727 & 0.943 & 0.881 & 0.648 \\
\hline rew & 1.000 & 1 & 0.035 & 1 & 1 & 0.035 \\
\hline sat & 0.606 & 0.606 & & 0.944 & 0.934 & \\
\hline tan & 1.000 & 1 & 0.515 & 1 & 1 & 0.515 \\
\hline tru & 0.672 & 0.672 & & 0.953 & 0.945 & \\
\hline zak & 1.000 & 1 & 0.038 & 1 & 1 & 0.022 \\
\hline
\end{tabular}

The model also meets SmartPLS's assumption: for example, average variance extracted (AVE) with communality score of $>0.5$ (see Table 16). These parameters are used for convergent validity. Cronbach's alpha and composite reliability with a score of $>0.7$ are used to test the reliability of the sample.

A bootstrapping test is used to check which variables affect the preferred variables significantly, in this case zakat as a tax deduction. Motivation factor has a significant negative effect $(5 \%, 2.03$ bigger than 1.96) in zakat preference. In the motivation variable, only reward factors have negative effects, but the correlation is significant. This means respondents prefer that nobody knows they have paid zakat. On the contrary, previous research by Siswantoro and Nurhayati (2012) concluded that motivation factor has a positive and significant correlation to zakat preference.

Satisfaction factor has a similar result with Siswantoro and Nurhayati's research (2012), which is negative and insignificant. Respondents feel unsatisfied with the zakat institution, which thus causes negative correlations to zakat preferences. Consistent patterns occur in this research. Only trust shows positive effects on zakat preference, but the correlation is not significant. Most respondents trust the zakat institution, which is actually a good thing. On the other hand, the zakat institution should enhance the transparency and accountability to make a better system. 
Table 17: Results of Bootstrapping Test

\begin{tabular}{|l|r|r|r|r|r|}
\hline & $\begin{array}{c}\text { Original } \\
\text { Sample } \\
(\mathbf{0})\end{array}$ & $\begin{array}{c}\text { Sample } \\
\text { Mean (M) }\end{array}$ & $\begin{array}{c}\text { Standard } \\
\text { Deviation } \\
\text { (STDEV) }\end{array}$ & $\begin{array}{c}\text { Standard } \\
\text { Error } \\
\text { (STERR) }\end{array}$ & $\begin{array}{r}\text { T Statistics } \\
\text { (|O/STERR|) }\end{array}$ \\
\hline mot -> alt & 0.999 & 0.999 & 0.000 & 0.000 & 33936.336 \\
\hline mot -> rew & -0.187 & -0.215 & 0.094 & 0.094 & 1.984 \\
\hline mot -> zak & -0.196 & -0.213 & 0.096 & 0.096 & 2.036 \\
\hline sat -> con & 0.912 & 0.910 & 0.025 & 0.025 & 35.614 \\
\hline sat -> emp & 0.905 & 0.903 & 0.018 & 0.018 & 48.883 \\
\hline sat -> rel & 0.715 & 0.722 & 0.046 & 0.046 & 15.256 \\
\hline sat -> res & 0.852 & 0.853 & 0.022 & 0.022 & 37.111 \\
\hline sat -> tan & 0.718 & 0.715 & 0.047 & 0.047 & 15.106 \\
\hline sat -> zak & -0.043 & 0.002 & 0.241 & 0.241 & 0.180 \\
\hline tru -> com & 0.887 & 0.882 & 0.027 & 0.027 & 32.404 \\
\hline tru -> cre & 0.977 & 0.976 & 0.006 & 0.006 & 162.215 \\
\hline tru -> mor & 0.869 & 0.862 & 0.034 & 0.034 & 25.107 \\
\hline tru -> zak & 0.162 & 0.135 & 0.207 & 0.207 & 0.783 \\
\hline
\end{tabular}

Figure 4: Bootstrapping test of second model result after loading $>0.7 \%$.

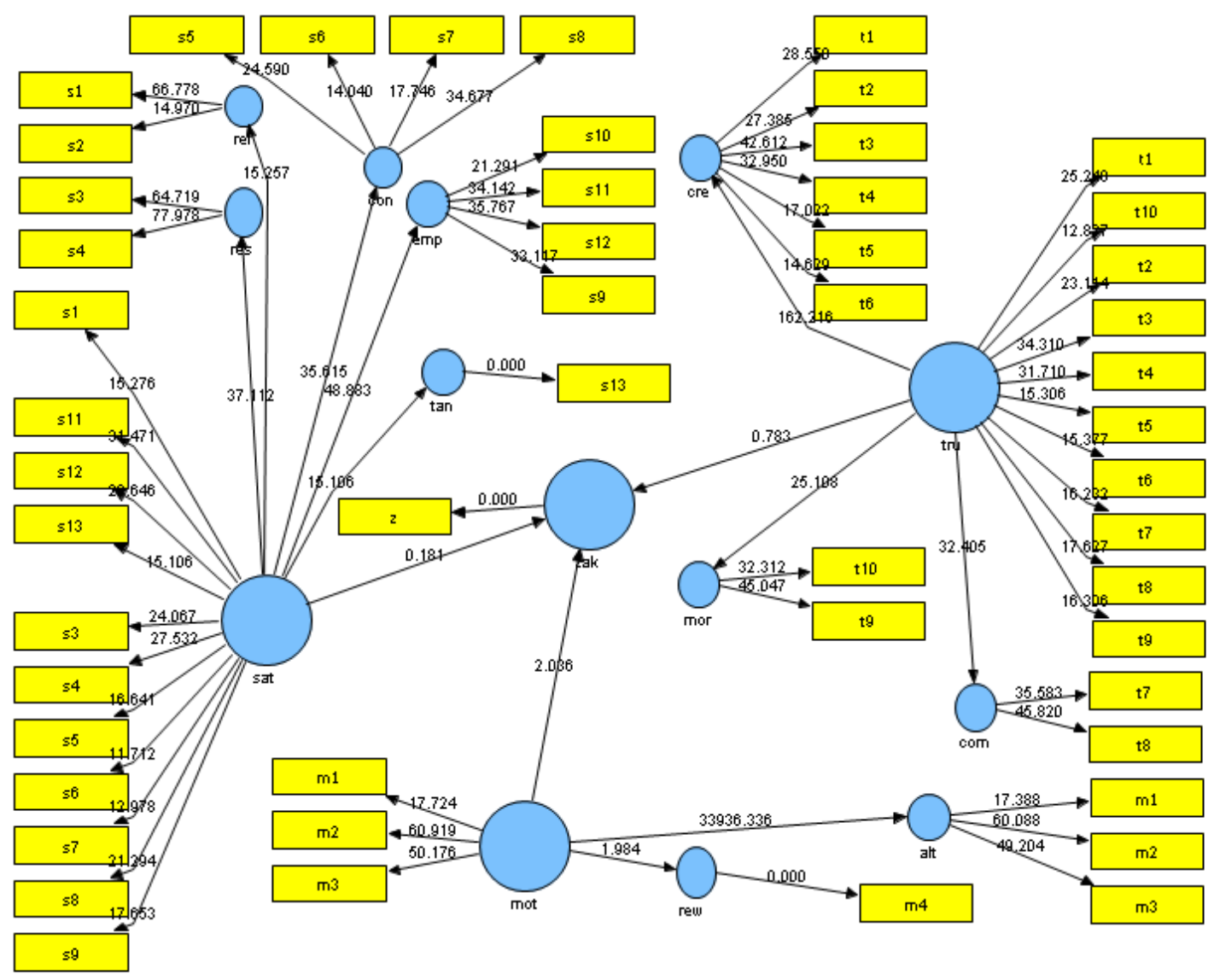




\section{CONCLUSIONS}

The results show that the awareness on the issue of zakat as a tax deduction is still low in Aceh, even though it has been regulated since 2006. Moreover, the awareness on the issue of zakat as a taxable income deduction is also low, even though it has been permitted since 1999. In fact, no one has claimed this for overpaid tax. The other issue is that the approved regulation has not been recognized by local Islamic law. In addition, the level of education affects the awareness of zakat as a tax deduction, especially for college graduates, which may be caused by the complexity of the issue.

The government should encourage citizens to have tax numbers because without them, it is impossible to claim zakat as a tax deduction. In addition, many state employees still pay zakat directly to recipients, even though there is an autodebit facility to pay zakat from a montly salary. This means that respondents assume it is more effective to pay zakat directly.

The results show interesting findings as the motivation variable shows a significant negative correlation with zakat preference. Although not significant, satisfaction shows a negative correlation, similar to the findings of Siswantoro and Nurhayati (2012). On the other hand, trust shows a postive correlation, but it is not significant. These results indicate that respondents are not quite satisfied with and do not trust zakat preference as a tax deduction. Besides, motivation has different views in this case. 


\section{References}

Anugrah, G. 2011. "Analisis Faktor-Faktor Yang Mempengaruhi Pembayaran Zakat Penghasilan Pada Badan Amil Zakat Terdaftar Di Pemerintah Kota Tanjungpinang." Universitas Indonesia.

Bakar, N.B.A. 2007. "A Zakat Accounting Standard (ZAS) for Malaysian Companies." The American Journal of Islamic Social Sciences 24 (4): 74-92.

Bakar, N.B.A., and A.R.A. Rahman. 2007. "A Comparative Study of Zakahand Modern Taxation." Journal of Islamic Economics JKAU 20 (10): 25-40.

Directorate General of Tax. 2011a. Implementation of Payment and Invoice of Zakat and Religious Obligatory Charity That Can Deduct Taxable Income.

__ 2011b. Registered Institution for Zakat Receiver. Directorate General of Tax Regulation.

Fatah, D. A. 2006. "Faktor-Faktor Yang Mempengaruhi Preferensi Karyawan Muslim Pertamina Dalam Membayar Zakat Profesi Melalui Baituzzakah Pertamina." Universitas Indonesia.

Jaelani, A. 2008. "Pengaruh Kualitas Pelayanan Dan Social Marketing Lembaga Amil (LAZ) Terhadap Keputusan Ber Zakat Muzakki (Studi Kasus: Pada Rumah Zakat Indonesia)." Universitas Indonesia.

Minister of State Secretariat. 2000. Taxable Income.

Ministry of Law and Human Rights. 2006. Government of Aceh.

Pollock, M. 2010. "Malaysia Tax Guide." PKF International Limited.

Prasetyo, M. E. 2013. "Analisis Faktor-Faktor Yang Mempengaruhi Pembayaran Zakat Penghasilan Pegawai Negeri Sipil Pemerintah Provinsi DKI Jakarta Pada Badan Amil Zakat Dan Infaq/Shadaqah (Bazis) Provinsi DKI Jakarta." Universitas Indonesia.

Regional Secretariat of Aceh. 2007. Baitul Mal. Qanun.

2008. Zakat Management Mechanism. Governor's Regulation of Nanggroe Aceh Darussalam.

Rizal, S. 2006. "Pengaruh Tingkat Kepuasan Dan Kepercayaan Muzakki Kepada Lembaga Amil Zakat Terhadap Perilaku Berzakat Muzakki." Universitas Indonesia.

Sariningrum, S. Z. 2011. "Analisis Faktor-Faktor Yang Memengaruhi Pembayaran Zakat Di Kota Palembang." Universitas Indonesia.

Siswantoro, D, and S. Nurhayati. 2012. "Factors Affecting Concern about Zakat as a Tax Deduction in Indonesia." International Journal of Management and Business Research 2 (4): 293-312. 
Takidah, E. 2004. "Analisis Pengaruh Kualitas Jasa Badan Amil Zakat Nasional Pada Kepuasan Dan Kepercayaan Muzakki." Universitas Indonesia. 


\section{Appendix}

List of Questions

\begin{tabular}{|c|c|c|c|c|}
\hline No & Group & Subgroup & Code & Statement \\
\hline 1. & Satisfaction & Reliability & s1 & $\begin{array}{l}\text { Zakat reception procedure of zakat institution } \\
\text { is quick and good. }\end{array}$ \\
\hline 2. & Satisfaction & Reliability & s2 & $\begin{array}{l}\text { Zakat disbursement procedure is on the right } \\
\text { target. }\end{array}$ \\
\hline 3. & Satisfaction & Responsiveness & s3 & $\begin{array}{l}\text { Zakat officer gives zakat information } \\
\text { responsively. }\end{array}$ \\
\hline 4. & Satisfaction & Responsiveness & s4 & $\begin{array}{l}\text { Zakat officer gives zakat information } \\
\text { comprehensively. }\end{array}$ \\
\hline 5. & Satisfaction & Confidence & s5 & Zakat institution manages the fund well. \\
\hline 6. & Satisfaction & Confidence & s6 & $\begin{array}{l}\text { I believe zakat institution can be trusted and is } \\
\text { professional in zakat management. }\end{array}$ \\
\hline 7. & Satisfaction & Confidence & s7 & $\begin{array}{l}\text { Zakat institution has published zakat fund- } \\
\text { reception report. }\end{array}$ \\
\hline 8. & Satisfaction & Confidence & s8 & $\begin{array}{l}\text { Zakat institution has published zakat fund- } \\
\text { disbursement report. }\end{array}$ \\
\hline 9. & Satisfaction & Empathy & s9 & I can contact zakat institution easily. \\
\hline 10. & Satisfaction & Empathy & $s 10$ & $\begin{array}{l}\text { I can use technology to pay zakat at a zakat } \\
\text { institution. }\end{array}$ \\
\hline 11. & Satisfaction & Empathy & s11 & $\begin{array}{l}\text { Zakat institution always maintains good } \\
\text { relationship with the zakat payer. }\end{array}$ \\
\hline 12. & Satisfaction & Empathy & $s 12$ & $\begin{array}{l}\text { Zakat institution always provides information } \\
\text { easily. }\end{array}$ \\
\hline 13. & Satisfaction & Tangible & $s 13$ & Zakat office is tidy and good. \\
\hline 14. & Trust & Credibility & $\mathrm{t} 1$ & $\begin{array}{l}\text { Zakat institution can be trusted with zakat } \\
\text { fund. }\end{array}$ \\
\hline 15. & Trust & Credibility & t2 & $\begin{array}{l}\text { Zakat institution has delivered zakat funds to } \\
\text { the right recipients. }\end{array}$ \\
\hline 16. & Trust & Credibility & t3 & Zakat institution has high credibility. \\
\hline 17. & Trust & Credibility & t4 & Zakat institution is trusted by society. \\
\hline 18. & Trust & Credibility & t5 & I believe in zakat institution. \\
\hline 19. & Trust & Credibility & t6 & $\begin{array}{l}\text { Zakat institution has been transparent in } \\
\text { financing. }\end{array}$ \\
\hline 20. & Trust & Competency & t7 & $\begin{array}{l}\text { Zakat institution officer has knowledge, } \\
\text { experience, and competence about zakat. }\end{array}$ \\
\hline 21. & Trust & Competency & t8 & $\begin{array}{l}\text { Zakat institution officer can manage zakat fund } \\
\text { well. }\end{array}$ \\
\hline
\end{tabular}




\begin{tabular}{|c|c|l|l|l|}
\hline 22. & Trust & Morality & t9 & $\begin{array}{l}\text { Zakat institution management has good } \\
\text { morals. }\end{array}$ \\
\hline 23. & Trust & Morality & t10 & $\begin{array}{l}\text { Zakat institution staff always maintain the } \\
\text { appearance }\end{array}$ \\
\hline 24. & Motivation & Altruism & $\mathrm{m} 1$ & I am pleased to be paying zakat for the poor. \\
\hline 25. & Motivation & Altruism & $\mathrm{m} 2$ & $\begin{array}{l}\text { I sympathize when seeing other people in } \\
\text { poverty. }\end{array}$ \\
\hline 26. & Motivation & Altruism & $\mathrm{m} 3$ & I feel comfortable after paying zakat. \\
\hline 27. & Motivation & Reward & $\mathrm{m} 4$ & I am pleased when people know I pay zakat. \\
\hline 28. & Zakat & Zakat & z & Zakat deducts tax that I paid \\
\hline
\end{tabular}

